Marta do Nascimento Silva

\title{
A Favela como expressão de conflitos no espaço urbano do Rio de Janeiro: o exemplo da Zona Sul carioca
}

Dissertação apresentada como requisito parcial para obtenção do grau de Mestre pelo Programa de PósGraduação em Geografia do Departamento de Geografia do Centro de Ciências Sociais da PUC-Rio.

Orientador: Prof. Dr. Alvaro Ferreira 


\section{A Favela como expressão de conflitos no espaço urbano do Rio de Janeiro: o exemplo da Zona Sul carioca}

Dissertação apresentada como requisito parcial para obtenção do grau de Mestre pelo Programa de PósGraduação em Geografia do Departamento de Geografia do Centro de Ciências Sociais da PUC-Rio. Aprovada pela Comissão Examinadora abaixo assinada.

Prof. Alvaro Ferreira

Orientador

Departamento de Geografia - PUC-Rio

Prof . João Rua

Departamento de Geografia - PUC-Rio

Prof. - Luciana Correa do Lago

Instituto de Pesquisa e Planejamento Urbano e Regional - IPPUR

Prof. a Mônica Herz

Coordenadora Setorial do Centro de Ciências Sociais - PUC Rio

Rio de Janeiro, 31 de março de 2010 
Todos os direitos reservados. É proibida a reprodução total ou parcial sem autorização da universidade, da autora e do orientador.

\section{Marta do Nascimento Silva}

Graduou-se bacharel e licenciada em geografia pela UERJ (Universidade do Estado do Rio de Janeiro) em 2007.

Ficha Catalográfica

Silva, Marta do Nascimento

A favela como expressão de conflitos no espaço urbano do Rio de Janeiro: o exemplo da zonal sul carioca / Marta do Nascimento Silva; orientador: Alvaro Ferreira. - Rio de Janeiro: PUC Departamento de Geografia, 2010.

157 f. : il.(color.) ; $30 \mathrm{~cm}$

1. Dissertação (Mestrado em Geografia)-Pontifícia Universidade Católica do Rio de Janeiro, Departamento de Geografia.

Inclui referências bibliográficas

1. Geografia - Teses. 2. Reprodução do espaço urbano. 3. Favela. 4. Luta de classes. 5. O direito à cidade. I. Ferreira, Alvaro. II. Pontifícia Universidade Católica do Rio de Janeiro. Departamento de Geografia. III. Título. 


\section{Agradecimentos}

Este trabalho foi fruto de grande esforço profissional e pessoal, devido a dificuldade constante de trabalhar e estudar ao mesmo tempo, fato comum durante toda a minha vida acadêmica. Por isso, hoje tenho a certeza de que sozinha tudo isto não seria possível, que sem a compreensão e o apoio de familiares, amigos e professores nunca teria concluído mais esta etapa.

Agradeço muitíssimo ao professor Alvaro Ferreira, meu orientador, que com muita paciência, amizade e boa vontade, muito contribuiu para minha formação acadêmica, me apresentando um "mundo" ao qual eu tinha pouco contato e com o qual acabei me identificando muito: a dialética. Com todas as dificuldades e toda a sua paciência, me ajudou a evoluir bastante, mesmo que ainda tenha um longo caminho pela frente.

Ao professor João Rua, que me acompanha de longa data e sendo um dos profissionais que mais admiro na carreira acadêmica, por estar sempre disponível e por aceitar tão gentilmente o convite de compor a banca examinadora.

A professora Luciana Correa do Lago, pelas contribuições durante a qualificação que muito ajudaram na organização do trabalho, pela atenção dada a pesquisa e o carinho com o qual aceitou compor a banca.

A todos os professores do Mestrado em Geografia da PUC-Rio, Rogério, Felipe, Ivaldo, Regina, Denise, enfim, que enriqueceram tanto esta caminhada. Aos funcionários 
do departamento de Geografia, em especial à Márcia e Edna, pela dedicação e o carinho aos alunos.

À PUC-Rio, pela oportunidade de realização deste projeto a partir de uma bolsa de estudos integral.

Muitos familiares e amigos participaram muito de perto da elaboração da pesquisa e não existem palavras para descrever o quanto foram importantes. Aos meus pais, que sempre me passaram a importância dos estudos e hoje tenho a consciência do quanto isso mudou nossas vidas. Em especial a minha mãe, que sempre deu todo o apoio e me ajudou muito, me "liberando" de muitos afazeres...

Meu marido Marcelo, que viveu essa fase "louca" comigo, participando desde o início de tudo, opinando e ajudando a dar o rumo a pesquisa e inclusive participando dos trabalhos de campo. Foram muitos finais de semana perdidos com leituras e campos, e apesar de tudo você sempre esteve ao meu lado. Existe uma razão para você estar ao meu lado, e agradeço a Deus todos os dias por isso.

Minha irmã Fernanda, que apesar de suas ocupações, sempre esteve presente, ajudando, participando e torcendo.

A minha sogra Luciene, que foi mais que uma amiga neste momento, foi uma mãe. Agradeço pelo empenho, pela ajuda e pela companhia nos árduos dias de PUC.

A amiga Andrea, pessoa especial que descobri após algum tempo de contato, e hoje vejo que sua amizade foi fundamental nesta jornada, muito tempo de estudo, muitas conversas e longas horas de viagem, mas que com você foram mais divertidas e felizes.

Hoje vejo que a distância, o cansaço, as inúmeras leituras, tinham uma razão de ser: o meu amadurecimento profissional e pessoal, e o tão sonhado título. Apesar de tudo, valeu a pena passar por tudo isso, por que vocês estavam ao meu lado. Obrigada. 


\section{Resumo}

Silva, Marta do Nascimento; Ferreira, Alvaro. A favela como expressão de conflitos no espaço urbano do Rio de Janeiro: o exemplo da Zona Sul Carioca. Rio de janeiro, 2010, 157p. Dissertação de Mestrado - Departamento de Geografia, Pontifícia Universidade Católica do Rio de Janeiro.

Este estudo é decorrente de uma inquietação a respeito de um tema bastante atual: A favela. A existência de uma crise urbana e habitacional na atualidade traz à tona a discussão sobre as favelas nas grandes metrópoles brasileiras, como uma das questões mais importantes a serem discutidas no espaço urbano. Cada vez mais as favelas estão evidenciadas na paisagem urbana, tornando-se necessário o entendimento da dinâmica das áreas faveladas e também da sua relação com a metrópole. Temos aqui o objetivo de mostrar a favela como a expressão de alguns conflitos no espaço urbano atual, utilizando como exemplo a Zona Sul da cidade do Rio de Janeiro, buscando apontar as principais contradições que envolvem a presença das áreas faveladas em bairros voltados para grupos sociais de alta renda na cidade. Buscamos, portanto, observar os elementos que expressam estes conflitos e entender até que ponto esta população favelada participa do cotidiano dos bairros em estudo, uma discussão que envolve, portanto, a questão do direito à cidade. Entendemos que estes conflitos são também simbólicos e perpassam a questão do estigma que envolve a favela e o favelado no Rio de Janeiro, por isso, buscamos também exemplificar o quanto estes conflitos e contradições contribuem para acirrar este estigma e a distância entre a favela e o bairro.

\section{Palavras-chave}

Reprodução do espaço urbano; favela; cotidiano; luta de classes; o direito à cidade. 


\section{Abstract}

Silva, Marta do Nascimento; Ferreira, Alvaro.. The slum as an expression of conflict in urban areas of Rio de Janeiro: the example of South Zone Carioca. Rio de Janeiro, 2010, 157 p. MSc. Dissertation - Departamento de Geografia, Pontifícia Universidade Católica do Rio de Janeiro.

This study is due to a concern about a very current topic: the slum. The existence of an urban and housing crisis in the news brings up the discussion on the slums in major Brazilian cities, as one of the most important issues to be discussed in the urban space. More and more are discussed in the slums in the urban landscape, making it necessary to understand the dynamics of slum areas and also its relationship with the metropolis. Here we have the objective of showing the slum as the expression of some conflicts in urban areas, utilizing the example of the South Zone of Rio de Janeiro, pointing the main contradictions involving the presence of the shantytowns in neighborhoods facing social groups high income in the city. We seek, therefore, to observe the elements that express these conflicts and to understand the extent to which this part of the slum population of the districts daily in the study, a discussion that involves, therefore, the issue of right to the city. We believe that these conflicts are also symbolic and run through the issue of stigma surrounding the slum and the slum in Rio de Janeiro, so, we seek also illustrate how these conflicts and contradictions contribute to exacerbate the stigma and the distance between the slum and the neighborhood.

\section{Keywords}

Reproduction of the urban; slum; everyday; class struggle; the right to the city. 


\section{Sumário}

$\begin{array}{ll}\text { 1. Introdução } & 10\end{array}$

2. A produção e reprodução do espaço urbano 24

2.1 O papel do espaço: o espaço como fonte de poder social 28

2.2 Sobre a importância da forma 38

2.3 O Processo de produção e reprodução no espaço urbano 40

2.4 Apropriação e dominação no urbano: conflitos e contradições 43

2.5 A dimensão do cotidiano como categoria de análise 53

2.6 direito à cidade $\quad 57$

3. As favelas no Rio de Janeiro: origem e situação atual 60

3.1 O surgimento das favelas na paisagem carioca 61

3.2 A expansão das favelas: Subúrbio e Zona Sul 64

3.3 A Chegada do migrante 69

3.4 A favela ganha destaque no cenário carioca: A atuação do poder público

4.1.1 A política de Remoções: a atuação do poder público na área mais valorizada da cidade

4.2. As favelas na Zona Sul

4.3. Conflitos e contradições - A idéia de fronteira como contato: como se dá a relação entre a cidade legal e a cidade ilegal

4.3.1 As áreas de contato entre o bairro e a favela

4.3.2 A natureza como fronteira - questão ambiental e a construção de muros 
4.3.4 A estigmatização do favelado: favela como locus da violência

4.3.5 $\mathrm{O}$ controle a partir da força: das incursões policiais às Unidades de Policias Pacificadoras

4.3.6 A "espetacularização" da pobreza: a favela como ponto turístico

Considerações finais

Referências

Anexos 